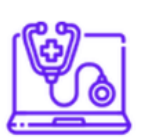

SAÚDE.ONLINE

Semana Online Científica de Saúde

22 a 24 de Novembro de 2021

\title{
CRYPTOCOCCUS UM PATÓGENO AMBIENTAL: ASPECTOS CLÍNICOS E SUA ASSOCIAÇÃO COM O DESFLORESTAMENTO NO ESTADO DO PARÁ.
}

\author{
Semana Online Científica da Saúde, 1 a edição, de 22/11/2021 a 24/11/2021 \\ ISBN dos Anais: 978-65-86861-84-6
}

BARATA; Rosendo Souza Barata ${ }^{1}$, SOUZA; Antonio Jorge Ataíde ${ }^{2}$

\section{RESUMO}

RESUMO A infecção causada pela levedura do complexo Cryptococcus gattii/ Cryptococcus neoformans apresenta-se de forma insidiosa na população mundial. A manifestação como doença reemergente em populações vulneráveis teve aumento significativo dos casos nos últimos quatro anos no estado do Pará. Esta pesquisa objetiva analisar as relações entre o perfil clínico e o desmatamento das áreas onde ocorrem os casos de meningite criptocócica na região paraense nos anos de 2014 a 2018. Estudo descritivo, transversal e ecológico correlacionando fatores clínicos da criptococose através de pesquisa documental em prontuários no Hospital Universitário "João de Barros Barreto" e sua distribuição espacial no estado do Pará. O perfil predominante foi à exposição ao agente por atividades agrícolas, aves e animais silvestres $(28,7 \%)$, como sinal os ligados a síndrome meníngea (45,2\%), cefaléia como sintoma $(81,7 \%)$, imunossupressão por HIV e associações (64,3\%) como antecedentes mórbidos e taxa de óbito total de $40 \%$. A análise espacial demonstrou a presença acentuada de casos em áreas desmatadas no território paraense. A elevada letalidade desta infecção é atribuída a fatores imunes do hospedeiro quando expostos a fontes ambientais do agente causador da doença e o curso da mesma deve ser levado em consideração em populações com alto risco de vulnerabilidade social.

PALAVRAS-CHAVE: meningite criptocócica, Condições sociais, fatores sócio econômicos, Distribuição espacial 